\title{
Assessing English Language Teachers' Awareness and Implementation of Motivational Strategies in EFL Class: Chilalo and Tokuma High Schools in Oromia Region Arsi Zone in Focus, Ethiopia
}

\author{
Habib Beshir \\ Department of English Language and Literature, Jimma University, Ethiopia \\ Email: habib889@gmail.com
}

http://dx.doi.org/10.18415/ijmmu.v5i3.358

\begin{abstract}
The main objective of this study was to assess the selected Ethiopian high schools English language teachers awareness and implementation of motivational strategies in EFL (English as a Foreign Language) classrooms. Relevant data were collected from two conveniently sampled high schools: Chilalo and Tokkummaa high schools. The tools used to collect data were questionnaire, interview, and observation. 419 students who were enrolled in the aforementioned high schools in 2018 filled out questionnaire. Interview with eleven purposively sampled English language teachers under the study area and classroom observation were also employed. Then the data gathered through questionnaire were analyzed using descriptive statistics in the form percentage and, mean and later interpreted. The data obtained though interview and observation were analyzed qualitatively through emerging trends. The result of this study revealed that, Grade nine English language teachers under the study area have good level of awareness regarding the motivational strategies. They believe that motivational strategies enhance the teachers to motivate students towards the target language and make the teaching-learning environment stimulating. However, although English language teachers under the study area have good awareness concerning the role of motivation in language teaching, the motivational strategies are not being implemented satisfactorily. Thus, English language teachers under the study area should implement motivational strategies in EFL class. Therefore, it would be possible to produce competent professionals and alleviate problems pertaining to teaching-learning environment of all Ethiopian state high schools in general and the selected high schools in particular.
\end{abstract}

Keywords: Awareness; Motivation; Implementation; Satisfactory; Competent

\section{Introduction}

It is undeniable fact that, in the field of education, motivation is one of the most decisive factors that determines the success and achievement of the learners in general and in EFL class in particular. In line with this idea, Cheng \& Dornyei (2007) confirm that, motivation serves as the initial engine to generate learning and functions as driving force that helps to sustain the long and laborious journey of acquiring second language. In addition, unquestionably it is fair to say that without sufficient motivation, learners are unlikely to continue long enough to achieve any useful language proficiency. 
Accordingly, Motivation research has received much attention in the past decade. The trend towards motivational theories related to classroom learning has generated more interest in the topic among language teachers and researchers of L2 (Second language). The previous researchers were exploring the role of L2 motivation, examining its complex nature and the way in which it affects the L2 learning process (e.g., Clément., 1980; Gardner., 1979; Oxford \& Shearin., 1994; as cited in Ushioda., 2009).

In Ethiopia though English language has been taught for a long period of time, many EFL learners find it boring, and being distressed even to develop their basic language skills. It is also common to hear many teachers complaining that these students are not willing to actively participate in the English language classes. In many instances, students face problems in learning English and are often lack willingness towards learning English language.

AlKaboody (2013), stated that, certain motivational strategies identified by research on motivation, can help learners adopt more positive attitudes towards language learning. Besides, motivational strategies in motivating learners should be seen as an important aspect of the study of second language. Similarly, Do rnyei, Z (2006), stated that with motivation being one of the key factors that determine success in L2 learning, strategies in motivating language learners should be seen as an important aspect of the theoretical analysis of L2 motivation. Therefore, this paper will explore English language level of awareness and implementation of motivational strategies in English language class.

\section{Basic Research Questions}

- What level of awareness does English language teacher have concerning motivational strategies in language classes?

- Are motivational strategies being implemented in language class?

- What challenges do English language teachers face when implementing motivational strategies in language class?

\section{Objectives \\ General Objective}

The general objective of this was to assess English language teachers' awareness level and implementation of motivational strategies in EFL classes.

\section{Specific Objectives}

Based on the above general objective, this study has the following specific objectives.

- To describe English language teacher's awareness regarding the use of motivational strategies in language classes

- To examine the implementation of motivational strategies in language classes

- To describe challenges that English language teachers face while implementing motivational strategies in language class 


\section{Significance of the Study}

The findings of the study will be used to raise teachers' awareness of practicing motivational strategies in the EFL profession particularly in language classes. Besides, it enhances language teachers to teach English in an effective and productive way by employing the motivational strategies. Moreover, based on the result of finding, this study will recommend possible solution regarding the practices of motivational strategies in language classes. It is also believed that this study will show the role that motivational strategies play in language teaching process. Finally, the findings of this study will help any motivated researchers to conduct and expand further studies on this area.

\section{Research Design}

In order to answer the questions raised in research question section, the research designed mixed method approaches. This means both qualitative and quantitative methods. As some scholars stated, mixed methods research, are important and useful to draw from the strengths and minimize the weaknesses of both in single research studies and across studies. Qualitative research design was employed in order to have a valid data for the study or to gain a better picture of the reality of the issue on the research questions and its objectives.

\section{Methodology Sampling Techniques and Sample Size}

This study was conducted in eastern part of Ethiopia, oromia region Arsi zone specifically tiyo district: Tokumma secondary school, and Chilalo secondary school. The schools were selected purposively to be the setting of the study.

\section{Participants of the Study}

There were two targeted groups in this study. The first group was all grade 9 English Language teachers of the selected study areas. Using purposive sampling method all of them were included as a sample because they are fewer in number and easy to manage. The second targeted group was grade 9 students of the school. According to the information gained from director of the school, there were 625 male and 744 female, totally 1369 students.

Out of total population,(1369) 30\% of (400) students were selected using systemic random sampling since random sampling, according to Bailey (1994), delivers chances for everyone to be a member of the sample.

\section{Data Gathering Instruments a. Classroom Observation}

The aim of the classroom observations was to find out how the teachers use of motivational strategies in EFL classroom. The conducted Observation was structured employing a checklist and compiled for analysis. Another reason of conducting class room observation was to cross check students response obtained through questionnaire. Accordingly, six classroom observations were conducted using observation checklists and made a tick using yes, no alternatives while the actual classroom was going. 


\section{b. Questionnaire}

For this study, questionnaire was prepared in English language. In order to avoid confusion and obtain relevant information, this questionnaire was translated in to students' mother tongue which is Afan oromo the dominantly spoken language in the study area. The translation was done by language experts to maintain its reliability and validity. 419 questionnaires in L1 were distributed to students to know their general understanding of literary texts and the extent of integration. Out of 419, 400 respondents completed the questionnaire and the remaining 19 questionnaires were rejected since there was incomplete information.

The Liker-type items of the questionnaires, which were constructed to check the implementation of motivational strategies (agree, disagree and not sure). The information gathered through questionnaire was edited, coded, classified, tabulated and completed as frequency, percentage, mean, and discussed accordingly.

\section{c. Interviews}

The researcher designed a semi-structured interview. The purpose of interviews was to find out English language level of awareness concerning motivational strategies and challenges the encounter when implementing motivational strategies in language class. Cross-checking of data obtained though questionnaires, and classroom observation was also made. The researcher purposively interviewed all English language teachers. Tape recorder was used to record the responses given by the respondents in addition to taking short notes. Finally, transcription was made to analyze the information.

\section{Discussion and Analysis}

As it can be deduced from the above table, the majority of respondents (181 or $45.3 \%$ ) responded that, their English language teachers do not establish a good teacher-student relationship in language class. Besides, classroom observation also reveals that, English language teachers of do not show harmonious relationship with their students in language class. According to (Dornyei., 2001a), creating basic motivational conditions through establishing a good teacher-student rapport, enhances students to learn the language in motivated manner.

Thus, establishing harmonious relationship with pupils and teacher is very vital in teachinglearning environment in general and language class in particular.

Concerning item 2, (creating a pleasant and supportive classroom atmosphere, and generating a cohesive learner group with appropriate group norms), most of the respondents (303, or 75.7\%) reflected that their English language teachers do not create pleasant and supportive classroom atmosphere.

Similarly, the respondents informed that although grade nine English language teachers of the study area allow learners to maintain a positive social image, and promote cooperation among the learners, they lack to achieve learning motivation by making learning stimulating though presenting tasks in a motivating way. In addition, Classroom observation also confirmed that students are taught from students' textbook. Regarding increasing learner satisfaction, and offering rewards and grades in a motivating manner, 245 (61.3\%) of informants relied that their English language teacher do not motivate them by increasing their satisfaction through rewards. 
Table 1 Analysis of students' response concerning implementation of motivational strategies in EFL class

\begin{tabular}{|c|c|c|c|c|c|c|c|c|c|}
\hline No. & Item & $\overrightarrow{\tilde{D}}$ & ટે & \multicolumn{6}{|c|}{ Responses } \\
\hline \multirow{3}{*}{1} & \multirow{3}{*}{$\begin{array}{l}\text { My teacher establishes a } \\
\text { good teacher-student } \\
\text { relationship }\end{array}$} & \multirow{3}{*}{$\mathrm{S}$} & & Agree & Not sure & Disagree & Mean & \multicolumn{2}{|r|}{ SD } \\
\hline & & & $\mathrm{f}$ & 55 & 164 & 181 & 2.89 & & 1.27 \\
\hline & & & $\%$ & 13.6 & 41 & 45.3 & & & \\
\hline \multirow{3}{*}{2} & \multirow{3}{*}{$\begin{array}{l}\text { My teacher creates a pleasant } \\
\text { and supportive classroom } \\
\text { atmosphere, and generates a } \\
\text { cohesive learner group with } \\
\text { appropriate group norms }\end{array}$} & $\mathrm{S}$ & & Agree & Not sure & Disagree & total & $\mathrm{M}$ & SD \\
\hline & & & $\mathrm{f}$ & 64 & 33 & 303 & 100 & & \\
\hline & & & $\%$ & 16.0 & 8.3 & 75.7 & 100 & & \\
\hline \multirow{3}{*}{3} & \multirow{3}{*}{$\begin{array}{l}\text { My teacher Maintains } \\
\text { motivation by making } \\
\text { learning stimulating though } \\
\text { presenting tasks in a motivate } \\
\text {-ing way, setting specific } \\
\text { learners' goal }\end{array}$} & $\mathrm{S}$ & & Agree & Not sure & Disagree & Total & $\mathrm{M}$ & SD \\
\hline & & & $\mathrm{f}$ & 81 & 100 & 219 & 100 & 2.89 & 1.27 \\
\hline & & & $\%$ & 45.3 & 33.3 & 52.7 & 400 & & \\
\hline \multirow{3}{*}{4} & \multirow{3}{*}{$\begin{array}{l}\text { My teacher allows learners } \\
\text { to maintain a positive social } \\
\text { image, promoting cooperat- } \\
\text { ion among the learners }\end{array}$} & \multirow{3}{*}{$S$} & $\mathrm{~F}$ & 219 & 85 & 96 & 400 & & \\
\hline & & & $\%$ & 52.7 & 35.3 & 45.3 & & & \\
\hline & & & $\%$ & & & & & & \\
\hline \multirow{3}{*}{5} & \multirow{3}{*}{$\begin{array}{l}\text { Increasing learner satisfactio- } \\
\mathrm{n} \text {, and offering rewards and } \\
\text { grades in a motivating } \\
\text { manner }\end{array}$} & & $\mathrm{f}$ & & & & & & \\
\hline & & \multirow[t]{2}{*}{$S$} & $\mathrm{f}$ & 96 & 36 & 268 & 400 & 3.62 & 1.3 \\
\hline & & & $\%$ & 24 & 9 & 67 & 100 & & \\
\hline \multirow[t]{2}{*}{6} & \multirow{2}{*}{$\begin{array}{l}\text { Creating learner autonomy } \\
\text { and promoting self- } \\
\text { motivating learner strategies }\end{array}$} & & $\mathrm{f}$ & 37 & 118 & 245 & 11 & 2.5 & 1.2 \\
\hline & & & $\%$ & 9.2 & 29.5 & 61.3 & 100 & & \\
\hline \multirow[b]{2}{*}{7} & \multirow{2}{*}{$\begin{array}{l}\text { providing motivational feed- } \\
\text { back and Encouraging } \\
\text { positive retrospective self- } \\
\text { evaluation by promoting } \\
\text { motivational attributions }\end{array}$} & \multirow[b]{2}{*}{$\mathrm{S}$} & $\mathrm{f}$ & 118 & 37 & 245 & 400 & 2.5 & 1.2 \\
\hline & & & $\%$ & 29.5 & 9.2 & 61.3 & 100 & & \\
\hline \multirow[t]{2}{*}{8} & \multirow{2}{*}{$\begin{array}{l}\text { protecting the learners' self- } \\
\text { esteem and increasing their } \\
\text { self-confidence }\end{array}$} & \multirow[b]{2}{*}{$\mathrm{S}$} & $\mathrm{f}$ & 54 & 141 & 205 & 400 & 2.7 & 1.25 \\
\hline & & & $\%$ & 13.5 & 35.2 & 51.3 & 100 & & \\
\hline
\end{tabular}

S: student

SD: Standard deviation

M: mean

F: frequency

Respondents from the sample population added that, motivational strategies such as creating learner autonomy and promoting self-motivating learner strategies, protecting the learners' self-esteem and increasing their self-confidence are not implemented in language class. 
On the other hand, some scholars (Cheng \& Dornyei., 2007) confirm that, motivation serves as the initial engine to generate learning and functions as driving force that helps learners to maintain the long and painstaking journey of acquiring second language.

\section{Analysis of Teachers' Interview}

To assess further information about English language teachers' level of awareness on motivational strategies, semi-structured interview for English language teachers was employed. Accordingly, a total of seven teachers were purposively selected and interviewed. Consequently, teachers' interview result was analyzed as follows:

The interviewees were separately interviewed concerning how they see the teaching of English language in general. In response to this question, all interviewees were replied that it is ok and they teach it comprehensively. Regarding the use of motivational strategies in EFL classes, the interviewees, replied that motivational strategies enhance the teachers to motivate students towards the target language and make the teaching-learning environment stimulating.

Besides, the interviewees added that implementing motivational strategies in language class facilitate the interaction and accelerate language learning in very simple way.

The second question asked the interviewees the challenges they face in implementing motivational strategies in language classes. Accordingly, they responded that large class size is one of the major challenges that they face in implementing motivational strategies in language classrooms. Therefore, in large class size it is very difficult to the teaching learning environment conducive.

In addition, they explained that motivating students in large class is challenging since monitoring all students requires patience. Most students have no willingness towards the target language, so that we face challenge in motivating these students although we tried our best said the informants. Similarly, the interviewees added that classroom setting and arrangement do not allow teachers to motivate students in language class.

\section{Conclusion}

The result of this study revealed that, Grade nine English language teachers under the study area have good level of awareness regarding the motivational strategies in EFL classrooms. They believe that motivational strategies enhance the teachers to motivate students towards the target language and make the teaching-learning environment stimulating. Similarly, the result obtained from the interviewees revealed that implementing motivational strategies in language class facilitates the interaction and accelerate language learning in very simple way. On the other hand, from the side of interviewees it was reflected that large class sizes and arrangement of classrooms as well as students' lack of willingness towards English language were challenges that impede implementation of motivational strategies in EFL class.

However, although English language teachers under the study area have good awareness concerning the role of motivation in language teaching, the motivational strategies are not being implemented satisfactorily. Relatively a greater number of respondents confirmed that, their English language teachers under the study area do not establish a good teacher-student relationship in language class in particular and nor do they implement other motivational strategies in general. Similarly, the result gathered through classroom observation also revealed that, English language teachers under the study area 
are not implementing motivational strategies in language class. This in return affects students' English language learning and academic enhancement in general.

\section{Recommendations}

Based up on the results of the study, the following recommendations were made:

If motivational strategies are implemented in EFL class effectively, undeniably producing competent and high caliber pupils in this fast-changing educational world becomes realistic.

The Ministry of Education together with the selected Ethiopian High schools should solve problems related to educational infrastructures such as expansion of classrooms so as to avoid large class size or number of students in a class So that teachers can easily encourage students and they can be motivated towards implementing the motivational strategies.

In other words, the selected school communities or concerned bodies should work on problems that impede the implementation of motivational strategies in EFL class. Besides, short term trainings concerning motivational strategies should be given to English language teachers of the selected study area.

School communities under the selected study area as well as students' parents should work on students' willingness towards education in general and English language in particular. Moreover, English language teachers under the study area should implement motivational strategies in EFL class.

Further researches should be conducted about Ethiopian high school English language teachers awareness and implementation of motivational strategies.

Thus, it would be possible to produce competent professionals and alleviate problems pertaining to teaching-learning environment of all Ethiopian state high schools in general and the selected high schools in particular.

\section{References}

Al Kaboody, M. (2013). Second Language Motivation; the Role of Teachers in Learners' Motivation Northern Arizona University. Available online @ www.academians.org.

AlshehrI, E. (2013). Motivational Strategies: the Perceptions of EFL Teachers and Students in the Saudi Higher Education Context.

Dörnyei, Z. (2001a). Motivational strategies in the language classroom. Cambridge: Cambridge University Press.

Do rnyei, Z. (2006). Creating a Motivating Classroom Environment. In J. Cummins and C. Davison (eds) the Handbook of English Language Teaching. New York: Springer.

Do rnyei, Z. (2006). Creating a motivating classroom environment. In J. Cummins and C. Davison (eds) the Handbook of English Language Teaching. New York: Springer. 
H-F. Cheng \& Z. Dornyei. (2007). The Use of Motivational Strategies in Language Instruction: The Case of EFL Teaching in Taiwan.

Dörnyei, Z. (2007a). Creating a Motivating Classroom Environment. In J. Cummins \& C. Davison (Eds.), International handbook of English language teaching. New York: Springer, 2: 719-731.

Dörnyei, Z. (2008). New Ways of Motivating Foreign Language Learners: Generating vision. Links, $38(1): 3-4$

Dörnyei, Z. (2009). The L2 Motivational Self System. In Z. Dörnyei \& E. Ushioda (Eds.). Motivation, language identity and the L2 self (p. 9-42). Bristol: Multilingual Matters.

Dörnyei, Z., \& Chan, L. (2013). Motivation and Vision: An Analysis of Future L2 Self Images, Sensory Styles, and Imagery Capacity Across Two Target Languages. Language Learning, 63(3): 437-462.

Dörnyei, Z., \& Clément, R. (2001). Motivational Characteristics of Learning Different Target Languages: Results of a Nationwide Survey. In Z. Dörnyei \& R. Schmidt (Eds.), Motivation and second language acquisition. (p. 399-432). Honolulu: University of Hawaii Press.

Gardner, R.C. (2001). Integrative Motivation and Second Language Acquisition. In Z.

Dornyei \& R. Schmidt (Eds). Motivation and Second Language Acquisition. Honolulu: University of Hawai'i Press, p. 1-19.

Ushioda, E. (2009). A Person-in-Context Relational View of Emergent Motivation, Self and Identity. In Z. Dörnyei \& E. Ushioda (Eds.), Motivation, language identity and the L2 self. Bristol: Multilingual Matters, p. 215-228.

\section{Copyrights}

Copyright for this article is retained by the author(s), with first publication rights granted to the journal.

This is an open-access article distributed under the terms and conditions of the Creative Commons Attribution license (http://creativecommons.org/licenses/by/4.0/). 